\title{
CATTLE EGRETS AS PESTICIDES BIOMARKER OF ENVIRONMENTAL POLLUTION IN KAFR EL-SHEIKH GOVERNORATE
}

\author{
*Hanaa, M.R. Hegazy; Haleem, H.H. and **Fatma, M. Fakhry \\ *Pharmacology and Toxicology Dept., Fac. Vet. Med. (Kafr El-Sheikh), Tanta University \\ **Biochemistry Dep., Animal Health Research Institute.
}

\begin{abstract}
The present study was conducted on cattle egret(Bubulcus ibis)as it was noticed a high incidence of mortality of it in a residential agricultural area, due to exposed to pesticide application (monocrotophos, thiobencarb,fluroxypyr and butachlor) in Kafr El-Sheikh Governorate. This work wasschemed to emphasize the main cause of toxicity induced by pesticides as well as some heavy metals as predisposing cause.

In this study 32 adult (o.3-o.5kg)alive cattle egrets exposed to these pesticides and 8 birds from pastures non-exposed to pesticides acted as controls for comparison, were caught and examined for bloodpicture and blood biochemistry.Also,pesticide residues and some heavy metals were determined in mud or soil, internal organs (liver, kidney, brain, ovaries, testes)and tissues of muscles,skin and feathers of contaminated birds. Birds exposed to pesticides showed anaemia which manifested by a marked drop in RBCs, $\mathrm{Hb}$ content and $\mathrm{PCV} \%$ as a result of disturbance in haemopoietic system. Meanwhile, leucocytosis, neutrophilia, monocytosis and lymphopenia were recorded in polluted birds which reflectdisturbancein immunesystemin responsetointoxication.However, basophils, eosinophils showed non-significant variation compared to controls. Elevation levels of AST, ALP and uric acid were observed in serum of polluted birds in comparison to control values, indicating the hepatorenal dysfunction. Nevertheless, serum values of ALT and creatinine did not alter.

Considerablepesticideresiduesweremeasured in mud and examined organs and tissues of contaminated birds. For exception, thiobencarb and butachlor could not be detected in the testes. The concentration levels of some heavy metals ( $\mathrm{pb}, \mathrm{Cd}, \mathrm{Cu}, \mathrm{Zn}, \mathrm{Mn}, \mathrm{Ni}$ ) were determined in mud,organsandtissues of pollutedbirds. Pb,Znand Nishowed theoverall
\end{abstract}


concentrations followed by $\mathrm{Cu}$ and $\mathrm{Mn}$. Whereas, Cd levels could be detected only in kidney and brain, while Mn was found in liver only.

It isconcluded from the current study that pesticides exhibited rapid deleterious effects on exposured cattle egrets which implicated significantlyimpairing function of liver and kidney as well as overt disorders in hsaemopoietic system as compared to respective controls.Despite of some heavy metals as well as bioconcentration of pesticide residues in organs and tissues reflect continuous toxicity.

It's inferred that the mortality of wild cattle egret is a biomarker of environmental pollution by pesticides.

\section{INTRODUCTION}

The intensive use of pesticides in recentyears in agriculture, veterinary practice and public health programmes has toxicological implications on environment in Egypt. The large use of pesticides represents one of the main causes of environmental pollution. These compounds have thepotential for causing toxicity (Yamanaka et al., 1996).

Furthermore, the impact ofheavymetals thatmay occursimultaneously in the environment,may indicate and alter the individual toxicities on living system, and can be found in all levels of polluted ecosystem and in living organisms, inhabiting such areas (Wren, 1986).

Metallic constituents of pesticide and therapeutic agents are additional sources of hazardous exposure. The burning fossilfuelscontainheavy metals. The addition of tetra ethyl lead to gasoline and in industrial applications of metals have now made environmental pollution and one of the major source of toxicity (Gilman et al., 1991).

Cattle egrets are beneficial to the environment and play an important role to livestock.The main source of toxicity for cattle egret population are pesticides and heavy metals.

The cattle egret (Bubulcns ibis) is an elegant white bird. These birds are considered to be both a beneficial insect predater as well as a nuisance to people and property (Snoddy,1969).Egrets walk very near to the cattle, picking insects from the animals and surrounding vegetation. Tho nirlrad horen flins and other nuisance flies from the cattle lower extr perched upon the animals backs to feed(Alderink and Dieu ı!, เ

Certainly, the egrets diet will be influenced by the abundance of insect species present in the areas where the birds are feeding. Cattle egrets pot-ential 
as a control agent for both forage insects and cattle ectoparasites apparently outweighs its potential threat as a purveyor of parasites and/or diseases of cattle (Rubin, 1983).

The impact of cattle egrets exposed to environmental pollutants such as pesticides and heavy metals is the aim of this study. These birds pose a threat to community health. The effect of pesticide residues on the lives-tock and crops, as well as problems that could arise drift or movement of the pesticide from his property to that of others.

So, the objective of the current study is to detect in appropriate way the cause of high incidence of mortality of cattle egrets nesting in pastures in Kafr El-Sheikh Governorate, where saturn, selectron and mashetpesticides were applied.The research was conducted on adult alive cattle egrets from these fields to study blood picture, blood biochemistry, estimation of the residue levels of these pesticides as well as the concentration levels of some heavy metals.

\section{MATERIALS AND METHODS}

\section{Test birds:}

Cattle egret (Bubilcns ibis) is a member of the Areidae(heran family) included in the order ciconiiformes (Strok-like birds). It is gregarious and usually associated with cattle and other grazing animals. Adults have wingspan and weight between $(0.3-0.5 \mathrm{~kg})$. The phrmage is white.

\section{Schedule of work:}

In this study,32adult alive birds of cattle egrets of both sexes in equal numberswere collected from farms in Kafr El-Sheikh city where monocrotophos (organophosphorus), thiobencarb (thiocarbamate), fluroxypyr (aryloxyalkanoic acid) and butachlor (chloroacetanilide) were applied.

Also, 8 birds were caught from pastures free from pesticides, act as controls.In addition,8samples of mud and soils werecollected forpesticide and heavy metals estimation, respectively.

\section{Sampling:}

Birds were sacrificed and each blood sample was collected in two portions. One portion was collected on heparin as anticoagulant to examine 
the blood picture. The other portion was collected to obtain serum. Then serum samples were kept in deep freeze $\left(-18^{\circ} \mathrm{C}\right)$ till biochemical analysis. Internal organs (liver, kidney, brain, ovaries, testes) were eviscerated and samples of muscles, skin, plumage were collected and kept in freeze till analysis for pesticide residues and metals.

\section{Blood picture:}

The heparinized blood samples were examined for blood picture.Haemoglobin content was estimated using cyanomethaemoglobin method of Crosby et al. (1954); packed cell volume(PCV) was determined by microhaematocriteapparatus according to Oser (1979); total erythrocytes(RBCs) and leucocytes (WBCs) counts (Nemi,1986); differential leucocytic count (Wintrobe et al., 1981).

\section{Biochemical analysis:}

Serum samples were examined for alanine aminotransferase activity (ALT), and aspartate aminotransferase activity (AST), according to the method of White et al.(1970); alkaline phosphatase activity(ALP)by using the method of Kind and King (1954), creatinine (Bartels, 1972); uric acid (Barham and Trinder (1972).

\section{Pesticide residue analysis:}

The residuallevels of accumulated pesticides in the examined samples were determined by a procedure described by AOAC (1980); Lawerenz (1983); Fried and Sherma (1996).

Samples were extracted with acetonitril (CH3CN), partitioned on Florisil column then eluted with mixture of petroleum ether and ether and measured by using thin layer chromatography. The quantitative assay was performed by UV-scan spectrophotometry. The validated sensitivity was \pm 0.001 with alimit of detection of $0.01 \mathrm{ppb}$,threshold0.( was $96 \%$. Samples was compared with standards of $t$

\section{Determination of heavy metals:}

One gram of each sample of soil or macerated organs or tissues, was placed in a clean-scraw tubes and digested according tothemethod described by Finerty et al. (1990). The obtained solutions were analyzed by using Kafr El-Sheikh Vet. Med. J. Vol. 1 No. 2 (2003) 
Air/Acetylene flame Atomic Absorption Spectrophotometer (UNICAM 696 AA spectrophotometer) for the determination of levels of lead $(\mathrm{Pb})$, cadmium $(\mathrm{Cd})$, copper $(\mathrm{Cu})$, zinc $(\mathrm{Zn})$, manganese $(\mathrm{Mn})$, Nickel $(\mathrm{Ni})$ in examined samples, in comparison to standards.

\section{Statistical analysis:}

The obtained datawerestatisticallyanalyzed and testedfor significance using "t" test according to Petrie and Watson (1999).

\section{RESULTS}

Data displayed in Tables1and 2show the blood picture of cattle egrets exposed topesticidescompared to non-exposed ones which act as controls. Table(1) indicates the drop in haematological values of Hb,PCV and RBC $(\mathrm{P}<0.05)$;however there is a marked augmentation in total leucocytic count in comparison to controls. Table(2)shows the differential leucocytic count which referred to a significant rise in neutrophils and monocytes $(\mathrm{P}<0.05)$, nevertheless a marked reduction in lymphocytes $(\mathrm{P}<0.05)$.

Table(3)demonstrates some serum biochemical values indicating the hepatorenal functions of the tested birds. Form this table, it is noticed the higher levels of AST, ALP and uric acid $(\mathrm{P}<0.05)$ of contaminated birds compared to controls.

Table (4) show the pesticide residues in mud and different tissues of cattle egretspolluted withpesticides. From this table, it is observed that there were considerable concentrations of pesticides in mud.Higher levels were found in ovaries, liver and kidney followed by brain, testes, muscles, feather and skin in the following magnitude order. Saturn and Mashet were undetectable in the testes.

Table (5) demonstrates various concentration levels of some heavy metals of $\mathrm{Ph}, \mathrm{Cd}, \mathrm{Cu}, \mathrm{Zn}, \mathrm{Mn}$ and $\mathrm{Ni}$, in minimum, maximum and mean values \pm S.E. The concentration levels of these metals were measured in soil and various tissues. Higher levels were recorded with $\mathrm{Pb}, \mathrm{Zn}, \mathrm{Ni}$ in all tissues than $\mathrm{Cu}, \mathrm{Mn}$ and $\mathrm{Cd}$. For exception, Mn could be detected only in liver and mud, while Cd could only be detected in kidney and brain.However,all the measured metals were high in mud. These levels were compared with the permissible limits of these metals in tissues according to the recommended international levels of permissible limits of metals in tissues (Table,6).

$\overline{\text { Kafr El-Sheikh Vet. Med. J. Vol. } 1 \text { No. } 2 \text { (2003) }}$ 
Table (1): Haematologicalvalues of cattle egrets exposed to pesticides compared with non-exposed ones (controls).

\begin{tabular}{||c|c|c|c|c||}
\hline Proup & $\begin{array}{c}\mathrm{Hb} \\
\mathrm{g} \%\end{array}$ & $\begin{array}{c}\text { PCV } \\
\%\end{array}$ & $\begin{array}{c}\text { RBCs } \\
\mathrm{X} 10^{6} / \mathrm{mm}^{3}\end{array}$ & $\begin{array}{c}\text { WBCs } \\
\mathrm{X} 10^{3} / \mathrm{mm}^{3}\end{array}$ \\
\hline \hline Control & $14.2 \pm$ & $39.6 \pm 1.3$ & $2.5 \pm 0.04$ & $40 \pm 2.2$ \\
\hline $\begin{array}{c}\text { Contaminated } \\
\text { birds* }\end{array}$ & $11.4 \pm 0.99 *$ & $25.6 \pm 2.7 *$ & $1.912 \pm 0.07^{*}$ & $82 \pm 1.53^{*}$ \\
\cline { 2 - 5 }
\end{tabular}

1

Table (2): Leucocytic differential count of pesticide-contaminated cattle egrets compared to controls.

\begin{tabular}{|c|c|c|c|c|c|}
\hline $\begin{array}{l}\text { Parameter } \\
\text { Group }\end{array}$ & $\begin{array}{c}\text { Neutrophils } \\
\%\end{array}$ & $\begin{array}{c}\text { Lymphocytes } \\
\%\end{array}$ & $\begin{array}{c}\text { Monocytes } \\
\%\end{array}$ & $\begin{array}{c}\text { Eosinophils } \\
\%\end{array}$ & $\begin{array}{c}\text { Basophils } \\
\%\end{array}$ \\
\hline Control & $19 \pm 2.14$ & $78 \pm 2.3$ & $2.0 \pm 0.01$ & $1 \pm 0.01$ & $0 \pm 0$ \\
\hline $\begin{array}{c}\text { Contaminated } \\
\text { birds* }\end{array}$ & $34 \pm 2.2^{*}$ & $61.4 \pm 3.3^{*}$ & $3.2 \pm 0.02 *$ & $2 \pm 0.05$ & $0.4 \pm 0.02$ \\
\hline
\end{tabular}

Table(3):Some liver and kidney function parameters of pesticide-contaminated cattle egrets compared to control

\begin{tabular}{|c|c|c|c|c|c|}
\hline Group & $\begin{array}{l}\text { ALT } \\
\text { U/L }\end{array}$ & $\begin{array}{l}\text { AST } \\
\text { U/L }\end{array}$ & $\begin{array}{l}\text { ALP } \\
\text { U/dl }\end{array}$ & $\begin{array}{l}\text { Uric acid } \\
\text { mg/dl }\end{array}$ & $\begin{array}{c}\text { Creatinine } \\
\mathrm{mg} / \mathrm{dl}\end{array}$ \\
\hline Control & $6.8 \pm 0.11$ & $20 \pm 0.21$ & $6.59 \pm 0.5$ & $6.86 \pm 0.12$ & $0.66 \pm 0.02$ \\
\hline $\begin{array}{l}\text { Contaminate } \\
\text { d birds* }\end{array}$ & $12 \pm 0.63^{*}$ & $36 \pm 0.45^{*}$ & $15.83 \pm 0.78^{*}$ & $\begin{array}{c}17.41 \pm \\
1.75^{*}\end{array}$ & $0.87 \pm 0.01$ \\
\hline
\end{tabular}

Data are represented in mean \pm S.E.

* Significantly different form concurrent controls at $\mathrm{P}<0.05$ using "t" t

$\overline{\text { Kafr El-Sheikh Vet. Med. J. Vol. } 1 \text { No. } 2 \text { (2003) }}$ 
Table (4): Pesticideresidues(ppm)in mud and various internal organs and tissues of cattle egrets exposed to pesticides.

\begin{tabular}{|c|c|c|c|c|c|c|c|c|c|}
\hline Pesticide & Liver & Kidney & Brain & Muscle & Testes & Ovary & Feather & Skin & Mud \\
\hline Monocrotophos & $\begin{array}{c}0.73 \pm \\
0.03\end{array}$ & $\begin{array}{c}0.39 \pm \\
0.02\end{array}$ & $\begin{array}{c}0.19 \pm \\
0.004\end{array}$ & $\begin{array}{c}0.13 \pm \\
0.01\end{array}$ & $\begin{array}{c}0.21 \pm \\
0.03\end{array}$ & $\begin{array}{c}0.71 \pm \\
0.04\end{array}$ & $\begin{array}{c}0.273 \pm \\
0.01\end{array}$ & $\begin{array}{c}0.27 \pm \\
0.002\end{array}$ & $\begin{array}{c}0.35 \pm \\
0.01\end{array}$ \\
\hline Thiobencarb & $\begin{array}{c}0.55 \pm \\
0.01\end{array}$ & $\begin{array}{c}0.264 \pm \\
0.01\end{array}$ & $\begin{array}{c}0.253 \pm \\
0.07\end{array}$ & $\begin{array}{c}0.22 \pm \\
0.01\end{array}$ & UD & $\begin{array}{c}0.44 \pm \\
0.01\end{array}$ & $\begin{array}{c}0.24 \pm \\
0.02\end{array}$ & $\begin{array}{c}0.14 \pm \\
0.03\end{array}$ & $\begin{array}{c}0.45 \pm \\
0.02\end{array}$ \\
\hline Flurokypyr & $\begin{array}{c}0.47 \pm \\
0.08\end{array}$ & $\begin{array}{c}0.21 \pm \\
0.06\end{array}$ & $\begin{array}{c}0.29 \pm \\
0.04\end{array}$ & $\begin{array}{c}0.161 \pm \\
0.004\end{array}$ & $\begin{array}{c}0.49 \pm \\
0.001\end{array}$ & $\begin{array}{c}0.41 \pm \\
0.003\end{array}$ & $\begin{array}{c}0.30 \pm \\
0.01\end{array}$ & $\begin{array}{c}0.291 \pm \\
0.03\end{array}$ & $\begin{array}{c}0.56 \pm \\
0.04\end{array}$ \\
\hline Butachlor & $\begin{array}{c}0.50 \pm \\
0.004\end{array}$ & $\begin{array}{c}0.26 \pm \\
0.001\end{array}$ & $\begin{array}{c}0.263 \pm \\
0.04\end{array}$ & $\begin{array}{c}0.203 \pm \\
0.02\end{array}$ & UD & $\begin{array}{c}0.39 \pm \\
0.02\end{array}$ & $\begin{array}{c}0.34 \pm \\
0.002\end{array}$ & $\begin{array}{c}0.37 \pm \\
0.01\end{array}$ & $\begin{array}{c}0.31 \pm \\
0.07\end{array}$ \\
\hline
\end{tabular}

$\mathrm{UD}=$ undetectable

Table (5): Concentration levels of some heavy metals in tissue of cattle egrets exposed to pesticides (ppm). 
Cattle Egrets As Pesticides Bllomarker Of Environmental...

Hanaa, M.R. Hegazy., et.al.

\begin{tabular}{|c|c|c|c|c|c|c|c|c|c|c|c|c|c|c|c|c|c|c|}
\hline \multirow{2}{*}{$\begin{array}{l}\text { Metal } \\
\text { Organ }\end{array}$} & \multicolumn{3}{|c|}{$\mathbf{P b}$} & \multicolumn{3}{|c|}{ Cd } & \multicolumn{3}{|c|}{ Cu } & \multicolumn{3}{|c|}{$\mathbf{Z n}$} & \multicolumn{3}{|c|}{ Mn } & \multicolumn{3}{|c|}{ Ni } \\
\hline & Min & Max & $\begin{array}{l}\text { Mean } \\
\pm \text { S.E. }\end{array}$ & Min & Max & $\begin{array}{l}\text { Mean } \\
\pm \text { S.E. }\end{array}$ & Min & Max & $\begin{array}{l}\text { Mean } \\
\pm \text { S.E. }\end{array}$ & Min & Max & $\begin{array}{l}\text { Mean } \\
\pm \text { S.E. }\end{array}$ & Min & Max & $\begin{array}{l}\text { Mean } \\
\pm \text { S.E. }\end{array}$ & Min & Max & $\begin{array}{l}\text { Mean } \\
\pm \text { S.E. }\end{array}$ \\
\hline Muscles & 19.591 & 27.046 & $\begin{array}{l}23.55 \\
\pm 1.26\end{array}$ & -ve & -ve & -ve & 5.318 & 7.446 & $\begin{array}{c}6.48 \\
\pm 0.36\end{array}$ & 21.302 & 48.799 & $\begin{array}{c}31.39 \\
\pm 5.2\end{array}$ & -ve & -ve & -ve & 2.724 & 14.56 & $\begin{array}{c}8.04 \\
\pm 2.28\end{array}$ \\
\hline Liver & 13.147 & 20.194 & $\begin{array}{l}15.67 \\
\pm 1.21\end{array}$ & -ve & -ve & -ve & 5.546 & 8.847 & $\begin{array}{r}7.89 \\
\pm 0.6\end{array}$ & 33.839 & 50.760 & $\begin{array}{r}43.44 \\
\pm 3.21\end{array}$ & 0.080 & 2.428 & $\begin{array}{c}1.79 \\
\pm 0.35\end{array}$ & 0.249 & 12.296 & $\begin{array}{r}6.63 \\
\pm 2.42\end{array}$ \\
\hline Kidneys & 20.819 & 32.202 & $\begin{array}{l}25.23 \\
\pm 2.48\end{array}$ & 0 & 0.003 & $\begin{array}{r}0.001 \\
\pm 0.001\end{array}$ & 2.838 & 4.486 & $\begin{array}{c}3.57 \\
\pm 0.33\end{array}$ & 14.023 & 18.515 & $\begin{array}{c}17.67 \pm \\
1.18\end{array}$ & -ve & -ve & -ve & 3.006 & 6.165 & $\begin{array}{c}4.35 \\
\pm 0.58\end{array}$ \\
\hline Skin & 8.784 & 23.627 & $\begin{array}{c}16.2 \\
\pm 2.55\end{array}$ & -ve & -ve & -ve & 1.870 & 8.177 & $\begin{array}{c}4.04 \\
\pm 1.13\end{array}$ & 15.606 & 42.492 & $\begin{array}{c}43.29 \\
\pm 15.08\end{array}$ & -ve & -ve & -ve & 2.539 & 5.326 & $\begin{array}{l}3.87 \\
\pm 0.5\end{array}$ \\
\hline Brain & 22.872 & 66.133 & $\begin{array}{l}49.29 \\
\pm 6.49\end{array}$ & 0 & 0.105 & $\begin{array}{c}0.018 \\
\pm 0.018\end{array}$ & 2.950 & 4.882 & $\begin{array}{c}3.63 \\
\pm 0.27\end{array}$ & 15.745 & 23.977 & $\begin{array}{l}18.58 \\
\pm 1.27\end{array}$ & -ve & -ve & -ve & 1.392 & 12.088 & $\begin{array}{c}8.04 \\
\pm 2.28\end{array}$ \\
\hline Feather & 21.897 & 32.766 & $\begin{array}{l}27.68 \\
\pm 3.16\end{array}$ & -ve & -ve & -ve & 2.976 & 8.045 & $\begin{array}{c}5.68 \\
\pm 1.47\end{array}$ & 16.668 & 46.457 & $\begin{array}{r}34.06 \\
\pm 8.95\end{array}$ & -ve & -ve & -ve & 0.306 & 12.869 & $\begin{array}{c}5.87 \\
\pm 3.70\end{array}$ \\
\hline Testes & 18.860 & 24.785 & $\begin{array}{l}21.61 \\
\pm 1.72\end{array}$ & -ve & -ve & -ve & 1.291 & 1.607 & $\begin{array}{l}1.41 \\
\pm 0.1\end{array}$ & 14.196 & 30.33 & $\begin{array}{l}20.64 \\
\pm 4.93\end{array}$ & -ve & -ve & -ve & 8.928 & 16.939 & $\begin{array}{l}12.72 \\
\pm 2.49\end{array}$ \\
\hline Ovaries & 19.320 & 27.455 & $\begin{array}{l}23.39 \\
\pm 4.07\end{array}$ & -ve & -ve & -ve & 1.644 & 2.966 & $\begin{array}{c}2.31 \\
\pm 0.66\end{array}$ & 29.778 & 59.225 & $\begin{array}{c}44.5 \\
\pm 14.72\end{array}$ & -ve & -ve & -ve & 0.233 & 6.787 & \\
\hline Mud & 37.851 & 41.785 & $\begin{array}{r}39.82 \\
+1.97 \\
\end{array}$ & 0.039 & 0.08 & $\begin{array}{c}0.06 \pm \\
0.001\end{array}$ & 72.991 & 106.29 & $\begin{array}{c}89.64 \\
\pm 16.65\end{array}$ & 91.625 & 113.99 & $\begin{array}{c}102.81 \pm \\
11.18\end{array}$ & 460.07 & 466.97 & $\begin{array}{l}463.52 \\
\pm 3.45\end{array}$ & 77.831 & 93.801 & $\begin{array}{l}85.82 \\
\pm 7.99\end{array}$ \\
\hline
\end{tabular}


Table (6): The recommended International levels of permissible limits (ppm) of some heavy metals in tissues.

\begin{tabular}{|c|c|c|}
\hline Metal & $\begin{array}{l}\text { Permissible } \\
\text { limit (P.L.) }\end{array}$ & Reference \\
\hline $\mathrm{Cd}$ & 0.05 & $\begin{array}{l}\text { FAO/WHO (1992) } \\
\text { Codex Alimentaries Commission }\end{array}$ \\
\hline $\mathrm{Pb}$ & 0.5 & $\begin{array}{l}\text { Standard program codex committee on food additive } \\
\text { and contaminants } 24^{\text {th }} \text { session Hange, 23-28 March. }\end{array}$ \\
\hline $\mathrm{Cu}$ & 20 & $\begin{array}{l}\text { Pearson, D. (1976) } \\
\text { The chemical analysis of food. }\end{array}$ \\
\hline$\overline{\mathrm{Zn}}$ & 50 & Churchill Livingston, London. \\
\hline
\end{tabular}

\section{RESULTS \& DISCUSSION}

In the present study, cattle egrets exposed to pesticides showed anaemia manifested by a marked drop in RBCs count, Hb content and PCV\% compared to controls. The decline in RBCs could be ascribed either to destruction of cells or their enhanced removal form circulation. Anaemia may result disturbed haemopiesis and decreased activities of superoxide dismutase, catalase and glutathione peroxidase in erythrocytes which are assumed to protect cytosolic proteins and membrane lipids that damaging effects of superoxide radicals and hydrogen peroxide (Sugawara et al., 1991).

Leucocytosis, neutrophilia, monocytosis and lymphopenia were observed in all contaminated birds. Leucocytosis due to intoxication, which may result lipid oxidation processes. The increase in leucocyte count may lead to the release of $(\mathrm{O}-2)$ radical and $\mathrm{H} 2 \mathrm{O} 2$ which may induce haemolysis (Sugawara et al., 1991).

The recorded depression in lymphocytes may reflect disturbance and stress to intoxication. States of stress induce increased secretion of glucocorticosteroids, a case which is usually met with lymphopenia (Ganong, 1995).

Neutrophilia may result from exposure to toxins or almost any tissue damaging process. Under such condition, the cell membrane bound enzyme 
NADPH oxidase is activated with the production of toxic oxygen metabolites. The activation of NADPH oxidase is associated with a sharp increase in O2 uptake and metabolism in neutrophil and generation of O2. the O-2 react spontaneously with $2 \mathrm{H}+$ to form $\mathrm{H} 2 \mathrm{O} 2$ in a reaction catalyzed by the cytoplasmic form of superoxide dimutase (Coles, 1986; Nemi, 1993).

The present data herein resulted in an elevation of enzyme activities of serum AST and ALP as well as uric acid levels in contaminated birds compared to respective controls. The rise in AST values may be attributed to the drastic condition caused by toxic chemicals and might provoke cellular destruction or an increased in the permeability of hepatic cells (Hawcroft, 1987).

Higher values of ALP may increase in cases of hepatocellular damage and cholestasis (Hawcroft, 1987). In coincidement, Gupta and Mali (1990) determined ALP in tissues and serum of uninfected cattle egrets.

Increased values of uric acid may be due to renal dysfunction. Higher levels of some uric acid of polluted birds is an indication of impaired glomerular filtration rate and/or due to corrupted renal function which may provide renal insufficiency (Kaneko, 1989).

The present data herein referred to considerable residue levels of examined pesticides in internal organs and tissues of contaminated birds as well as variable concentration levels of some heavy metals. Similar results in cattle egrets were recorded by Lincer et al. (1981) in Kenya's Rift vallg (organochlorine residues of DDT, dieldrin, toxaphane, dioxathion, DDE); Mullie et al. (1992) estimated organochlorine (HCB, Lindane, p-p'-DDE, PCBs) as well as mercury in Faiyum Oasis, Egypt. Ramesh et al. (1992) measured the residue levels of organochlorine compounds such as HCM isomers, DDT compounds, polychlorinated biphenyls (PCBs) and hexachlorobenzen in India. Mora and Miller (1998) estimated DDE, polychlorinated biphenyls, hexachlorobenzen, HCH and p-p'DDT in Bryan, Texas.

Accumulation of metals and pesticide residues in the body cells of cattle egrets in this work is a marker of persistence of toxicity. Sexual dif-ferences in residue and accumulation revealed that the levels were almost similar. The residue accumulation as a function suggests that the differences in contaminant levels in sexes were due to variations in exposure rather than the biological events.

$\overline{\text { Kafr El-Sheikh Vet. Med. J. Vol. } 1 \text { No. } 2 \text { (2003) }}$ 
Chemicals have removed from sites of application by air, water and other routes result in their wide spread distribution in all living organism (WHO, 1986).

Exposure to metallic hazards might have been due to abnormally high natural concentration in the food or water. The use of metal slats or other inorganic toxic material as pesticides increased the risk for hazardous exposure. Later mortality or toxicity related to pollution of environment form industrial contaminants were recognized (Cassarett and Doul, 1980). Heavy metals effects by combining with one or more reactive groups essential for normal physiological function (Gilman et al., 1991).

The toxicological appraisal of the relative contribution of the examined pesticide residues in cattle egrets indicate that pesticide levels are highest in tissues and sediment. Their residue levels may increase further in birds and farm animals in the future due to the continuing usage of these chemicals and also through bioaccumulation in the food chain.

In the view of the intensive consumption of pesticides in developing countries, there is a likelihood that in wild birds future residue levels eventually lead to a decline in population density (Koeman et al., 1971).

Increased build-up of toxicants as a result of prolonged exposure may not only affect the resident wild birds, but also the migratory ones when they visit point-source areas for wintering and breeding purposes (Ramesh et al., 1992). Cattle egrets are mainly insectivores. They feed in agricultural areas. Cattle egrets in Northern Africa are generally residents. In Egypt, the cattle egret is a common resident bird of the Nile valley (Mullie et al., 1992).

The intensive use of pesticides to eliminate pests or to regulate crop growth has led to pesticide residues in soil, air, water, stored grains, crops and plants (Susse and Muller, 1996). The great hazards caused by pesticides are due to accidental exposure to these chemicals either by inhalation, skin absorption and/or ingestion (Yamanaka et al., 1996). Pesticides can be nore dangerous chemicals

Conclusively, this study provides baseline data on pesticides and heavy metals on the basis of their toxicity. Overall, pesticides are the main cause of mortality of wild cattle egrets. It is noteworthy to mention that cattle egrets which forage mainly on insects in agricultural areas are likely to be good indicator for pesticide use in these habitats.

$\overline{\text { Kafr El-Sheikh Vet. Med. J. Vol. } 1 \text { No. } 2 \text { (2003) }}$ 
So, for the health and welfare of general population, application of pesticides must be supervised and restricted to minimize contamination of the environment.

\section{REFERENCES}

- A.O.A.C.(1980): "Official Methods of Analysis of the Association of Official Analytical Chemists.” Horwitz, W. (ed.), $13^{\text {th }}$ Ed., p. 121, published by the Association of Official Analytical Chemists, Benjamin Franklin Station,Was-hington, D.C., 2004.

- Alderink,F.J.and Dietrich, A.(1983): "Economic and epidemiological impl-ications of anaplasmosis in Texas beef cattle herds.”Texas Agricultural Exper-iment Station B-1426, Texas A \& M University, College Station, Tx, 16 pp.

- Barham, D. and Trinder, P. (1972): "Enzymatic determination of uric acid.” Analyst, 97: 142-145.

Bartels, H. (1972): “Determination of creatinine.”Clin.Chem. Acta, 37:193197

- Cassarett, L.J. and Doul, J.(1980): "Toxicology, The Basic Science of Poisons" $2^{\text {nd }}$ Ed., MacMillan Publishing Co., INC, New York.

- Coles, E.H.(1986): "Veterinary Clinical Pathology" $4^{\text {th }}$ Ed., W.B. Saunders Company, Philadelphia, London, Toronto.

- Crosby, M.E.; Munn, J.I. and Furth, F.W.(1954): "Standardizing a method for clinical haematology" USA, Armed Forces Med. J., 5: 693703.

- FAO/WHO (1992): "Codex alimentarius commission, standard programme codex committee on food additives and contaminants $24^{\text {th }}$ Session, Hauge, 23-28, March 1992.

- Finerty, M.W.; Madden, J.D.; Feagly, S.E. and Grodner, R.M. (1990): "Effects of environs and seasonality on metal residues in tiscries of varild and pond raised Cray fish in Southern Louisiana.” Arch E] Toxicol., 19: 49.

- Fried, B. and Sherma, J. (1996): "Practical thin layer chromatography. A multidisciplinary Approach.” $1^{\text {st }}$ Ed., pp. 252-253, CRC Press Boca Raton, New York, London, Tokyo. 
- Ganong,W.F. (1995): “A Lange Medical Book Review of Medical Physiology" $15^{\text {th }}$ Ed., p.278, Middle East Edition,Librairie du Liban P.O. Box 945, Beirut, Lebanon, Appleton and Lange, Norwalk Connecticut/Los Altos, California.

- Gilman,A.G.; Rall, T.W.; Nies, A.S. and Taylor, P. (eds) (1991): "Goodman and Gilman's:The Pharmacological Basis of Therapeutics." ${ }^{\text {th }}$ Ed.,Pergamon Press,Member of Maxwell MacMillan Pergamon Publishing Corporation New York, Oxford, Beijing, Frankfurt, Sydney, Toronto.

- Gupta,I.and Mali,K.L.(1990):“Alkaline and acid phosphatases in the tissues and serum of uninfected and infected host cattle egrets (Bubulcus ibis corom-andus) infected with a digenetic trematode Pegosomum egretti.” Rivista-di-Parassitologia, 49 (2): 227-232.

- Hawcroft,D.(1987): "Diagnostic Enzymology." $1^{\text {st }}$ Ed.,John Wiley and Sons, Chichester, New York, Brisbane, Toronto.

- Kaneko, J.J. (1989): "Clinical Biochemistry of Domestic Animals." $4^{\text {th }}$ ed., Academic Press, Inc. Harcourt Brace Jovanovich,Publishers, San Diego, New York, Berkeley, Boston, London, Sydney, Tokyo, Toronto.

- Kind, P.R.N. and King, E.G. (1954): "Enzymatic determination of serum alkaline phosphatase.” J. Clin. Path., 7: 322-331.

- Koeman,J.H.; Rijksen,H.D.;Smies,M.;Na'isa, B.K. and MaClennan, K. $\boldsymbol{J R}(1971)$ : "Annual changes in swamp habitat in Nigeria sprayed with insecticide to exterminate Glossina.” Neth. J., 21: 434-463.

- Lawerenz,A.(1983): "Analysis of triazine herbicide in water by thin layer chr-omatography.” Acta Hydrobiologica, 11 (3): 347-350.

- Lincer, J.L.; Zalkind, D.; Brown, L.H. and Hopcraft, J. (1981): “Organoc-hlorines residues in Kenya's Rift valley lakes.” J. Appl. Ecol.,18 (1):157-171.

- Matsumura, F. (1985): “Toxicology of Insecticides.” $2^{\text {nd }}$ Ed.,Plenium Press, New York, pp. 267-270.

- Mora, M.A. and Miller,J.M. (1998): "Foraging flightc ronrndurtivo 18,50

- Mullie, W.C.; Massi, A.; Focardi, S. and Renzoni,A.(1992):"Residue levels of organochlorines and mercury in cattle egret, Bubulcus ibis, eggs from the Faiym Oasis, Egypt.” Bull. Environ. Contam. Toxicol., 48 (5): 739746 . 
- Nemi, C.J. (1986): "Schalm's Veterinary Haematology” $4^{\text {th }} \quad$ Ed, Lee and Febiger, Philadelphia.

- Nemi, C.J.(1993): “Essentials of Veterinary Haematology.” Lee and Febiger, Philadelphia.

- Oser, B.L. (1979): "Hawk's physiological chemistry" $14^{\text {th }} \quad$ Ed., p.337, McGraw-Hill Publishing Co., Ltd, New York.

- Pearson, D. (1976): "The chemical analysis of food." Churchill, Livingston, London.

- Petrie,A.and Watson,P.(1999):"Statistics for Veterinary and Animal Science” $1^{\text {st }}$ Ed., pp. 90-99, The Blackwell Science Ltd, United Kingdom.

- Ramesh, A.; Tanabe, S.; Kannan, K.; Subramanian, A.N.; Kumaran, P.L. and Tatsukawa, R. (1992): "Charsetritcs trend of persisted organochlorine contamination in wild like form a tropical agricultural watershed,South India" Archives of Environmental Contamination and Toxicology, 23 (1): 26-36.

- Rubin, S. (1983): "Birds outnumber residents, take over small town." Bryan College Station Eagle, Aug. 7, p 2 AA.

- Snoddy,E.L.(1969): "On the behavior and food habits of the cattle egret, Bub-uleus ibis (L.).” J. Georgia Entomol. Soc., 4 (4): 156-158.

- Sugawara, E.; Nakamura, K.; Miyake, T.; Fukumurta, A. and Sekie, Y. (1991): "Lipid peroxidation and concentration of glutathione in erythrocytes from workers exposed to lead.” Brit. J. Indust. Med., 48: 239242.

- Susse, H. and Muller, H.(1996): "Pesticide analysis by micellar electrokinetic capillary chromatography.” J. Chrom., a, 730: 337-343.

- White, B.A.; Erickson,M.M. and Sevens, S.C.(1970): "Chemistry for

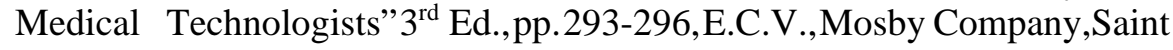
Louis,USA.

- WHO (1986): "Environmental health criteria. 63: Organophosphorus insect-icides.” A General Introduction.” Geneva, World Health Organization,pp.181.

- Wintrobe,M.M.;Lee, G.R.;Boggs.D.R.; Bithell, T.C.;Foerater,J.;Athnes, J. W. and Lukens, J.N. (1981): “Clinical Haematology." $8^{\text {th }}$ Ed., pp. 2155285, Lee and Febiger, Philadelphia, USA.

- Wren, C.D. (1986): "A review of metals accumulation and toxicity wild mammals. I. Mercury.” Environ. Res., 40: 210-244.

- Yamanaka,S;Ohta,K.I.;Tomita,Y.;Tokayanagi,A.;Nomura,T.and Takaesu, Y.(1996):"Effects on acute organophosphorus poisoning in rats in aging and solubility of organophosphates." Enviorn. Health, Prev. Med., 1 (3): 119-127. 